\title{
Nordic Jews in the twentieth and twenty-first centuries
}

\author{
REPORTS
}

DOI: https://doi.org/10.30752/nj.99325

Conference report on the online workshop Nordic Jews in the 20th and 21st centuries: 'Multiple Identifications in Everyday Life', organised by Professor Lena Roos, 15-16 October 2020.

An online workshop, 'Multiple Identifications in Everyday Life', organised by Lena Roos, Professor of the Study of Religions at Södertörn University, was held online on I $5^{-1} 6$ October 2020. Senior and junior researchers, as well as other participants in various fields related to Jewish studies, participated in the workshop, which brought together the following interrelated research projects:

I. 'Boundaries of Jewish Identities in Contemporary Finland - "Minhag Finland"' (PI Ruth Illman), funded by the Polin Institute for Theological Research, Åbo Akademi University, Finland;

2. 'Should I Stay or Should I Go? Contemporary Jewish Identity in Relation to Place and Language' (PI Lena Roos), Södertörn University;

3. 'Traces of Yiddishkeit: The Yiddish Collection at the Jewish Library'(PI Lena Roos), funded by the Swedish Foundation for the Humanities and Social Sciences;
4. 'Rehabilitation and Integration of Holocaust Survivors in Sweden, I 945-55' (PI Pontus Rudberg), funded by the Swedish Research Council;

5. 'Negotiating Jewish Identity: Jewish Life in Twenty-first Century Norway (PI Cora Alexa Døving), funded by the Norwegian Research Council, University of Oslo/ HL-Sentret, Oslo;

6. 'The Migrant Generation of 68' (Martin Englund), doctoral project, funded by Södertörn University, Sweden.

Altogether, approximately twenty scholars from the Nordic and the Baltic countries attended the online workshop. The theme of the conference was research on contemporary Judaism in the Nordic countries. The aim of the workshop was to establish a stronger collaborative network between both research teams and individual scholars, including participants of various disciplines from the University of Helsinki, Åbo Akademi University, the Donner Institute, Södertörn University, HL-Sentret, Uppsala University, the Jewish Library in Stockholm and the University of Oslo.

The participants discussed recent and ongoing projects related to Jewish identity in the Nordic countries, archival projects, teaching Jewish studies on various levels, 
interviewing and fieldwork. Practical information, such as funding and grant possibilities on a smaller and larger scale, were also discussed, and the participants discussed various possible joint projects and future cooperations.

The small number of participants made it possible to discuss in-depth theoretical and methodological issues and aspects emerging during the research. The workshop also included an open online lecture by Cora Alexa Døving, Research Professor at the Norwegian Center for Holocaust and Minority Studies, with the title 'Jewish or minority-ish? Jewish identity in multicultural Norway', followed by a discussion.

Several ideas and suggestions were developed in parallel during the workshop. In the session on archival work, it was decided that a survey would be conducted to map out what has been done so far in the Nordic countries concerning archival research on Jewish topics. A summarising article on the Nordic Archives keeping Jewish documents will be compiled by Docent Simo Muir and collaborators. The workshop also included a session on interviewing and ethnographic research, headed by Docent Ruth Illman, where the participants discussed epistemological, methodological and practical issues relating to ethnographic research on Jewish topics, including data management, as well as ethical issues and comparability. A presentation on funding possibilities in the Nordic countries was also given by administrative experts from Södertörn University, whereby workshops, more complex applications and infrastructure could be financed in the future. In the last session, entitled 'Students as researchers', the participants discussed how for example BA and MA theses could be made more available and, in some instances, also published.

During the second day of the workshop, a session was arranged on 'Teaching Jewish studies in the Nordic countries'. Here, an initiative was launched: to compile a shared online Nordic textbook for Jewish studies (BA/MA level) in English or the local languages on Jewish history and Jewish studies including Holocaust education.

The participants are committed to strengthen the co-operation among the particular projects and also elaborate on future joint projects on Nordic Jewry after mapping the funding opportunities. A broader collaboration with the Nordic Network for Jewish Studies, hosted at Lund University, and with the journal Nordisk judaistik Scandinavian Jerwish Studies is also planned. We are looking forward to the next workshop at Åbo Akademi University, organised by the Minhag Finland group to take place in May $202 \mathrm{I}$.

DÓRA PATARICZA

Post-doctoral researcher, Åbo Akademi University 